\title{
Anticancer Drugs for Intra-Arterial Treatment of Colorectal Cancer Liver Metastases: In-Vitro Screening after Short Exposure Time
}

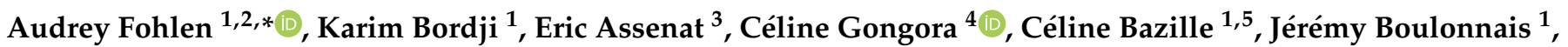 \\ Mikaël Naveau ${ }^{6}{ }^{(0)}$, Cécile Breuil ${ }^{7}$, Elodie A. Pérès ${ }^{1}{ }^{1}$, Myriam Bernaudin $^{1}{ }^{\circledR}$ and Boris Guiu ${ }^{8}(\mathbb{D}$
}

1 UNICAEN, CEA, CNRS, ISTCT/CERVOxy Group, GIP CYCERON, Normandie University, 14000 Caen, France; bordji@cyceron.fr (K.B.); bazille-c@chu-caen.fr (C.B.); boulonnais@cyceron.fr (J.B.); peres@cyceron.fr (E.A.P.); bernaudin@cyceron.fr (M.B.)

2 Urodigestive Imagery and Interventional Radiology Department, University Hospital of Caen, CEDEX, 14000 Caen, France

3 Medical Oncology Department, Montpellier School of Medicine, Saint-Eloi University Hospital, 80 Avenue Augustin Fliche, 34295 Montpellier, France; e-assenat@chu-montpellier.fr

4 IRCM, Montpellier Cancerology Research Center, INSERM U1194, Montpellier University, Montpellier Regional Institute of Cancer, 34298 Montpellier, France; celine.gongora@inserm.fr

5 Department of Pathology, University Hospital of Caen, CEDEX, 14000 Caen, France

check for updates

Citation: Fohlen, A.; Bordji, K.; Assenat, E.; Gongora, C.; Bazille, C.; Boulonnais, J.; Naveau, M.; Breuil, C.; Pérès, E.A.; Bernaudin, M.; et al. Anticancer Drugs for Intra-Arterial Treatment of Colorectal Cancer Liver Metastases: In-Vitro Screening after Short Exposure Time. Pharmaceuticals 2021, 14, 639. https://doi.org/ 10.3390/ph14070639

Academic Editors: Murtaza.

M. Tambuwala, Michela Roberto and Hamid Bakshi

Received: 18 June 2021

Accepted: 26 June 2021

Published: 1 July 2021

Publisher's Note: MDPI stays neutral with regard to jurisdictional claims in published maps and institutional affiliations.

Copyright: (C) 2021 by the authors. Licensee MDPI, Basel, Switzerland. This article is an open access article distributed under the terms and conditions of the Creative Commons Attribution (CC BY) license (https:// creativecommons.org/licenses/by/ $4.0 /)$.
6 UNICAEN, CNRS, UMS 3408, GIP CYCERON, Normandie University, 14000 Caen, France; naveau@cyceron.fr

7 Pharmacy Department, University Hospital of Caen, CEDEX, 14000 Caen, France; breuil-c@chu-caen.fr

8 Radiology Department, Montpellier School of Medicine, Saint-Eloi University Hospital, 80 Avenue Augustin Fliche, 34295 Montpellier, France; b-guiu@chu-montpellier.fr

* Correspondence: fohlen@cyceron.fr; Tel.: +33-616702414

\begin{abstract}
To treat colorectal liver metastases, intra-arterial chemotherapies may complete therapeutic arsenal. Drugs using intra-arterially are very heterogeneous. The aim of this study was to select the most efficient drug on a panel of colorectal cancer (CRC) cell lines (Caco-2, HCT 116, HT 29, SW 48, SW 480, SW 620) exposed for $30 \mathrm{~min}$ to 12 cytotoxic agents (doxorubicin, epirubicin, idarubicin, 5-FU, raltitrexed, gemcitabine, cisplatin, oxaliplatin, mitomycin C, irinotecan, streptozocin, paclitaxel) at different concentrations. The effect on cell viability was measured using the WST-1 cell viability assay. For each drug and cell line, the $\mathrm{IC}_{50}$ and $\mathrm{IC}_{90}$ were calculated, which respectively correspond to the drug concentration $(\mathrm{mg} / \mathrm{mL}$ ) required to obtain $50 \%$ and $90 \%$ of cell death. We also quantified the cytotoxic index $\left(\mathrm{CyI}_{90}=\mathrm{C} \mathrm{Max} / \mathrm{IC}_{90}\right)$ to compare drug efficacy. The main findings of this study are that idarubicin emerged as the most cytotoxic agent to most of the tested CRC cell lines (Caco-2, HT29, HCT116, SW620 and SW480). Gemcitabine seemed to be the most efficient chemotherapy for SW48. Interestingly, the most commonly used cytotoxic agents in the systemic and intra-arterial treatment of colorectal liver metastasis (CRLM) (oxaliplatin, 5-FU, irinotecan) showed very limited cytotoxicity to all the cell lines.
\end{abstract}

Keywords: antineoplastic agents; colorectal neoplasms; hepatic artery; liver neoplasm; in vitro screening

\section{Introduction}

Colorectal cancer (CRC) represents the third most common type of cancer in the world and the second in terms of cancer mortality [1]. Synchronous colorectal liver metastases (CRLM) occur in up to $50 \%$ of patients [2]. Complete surgical resection represents the best treatment for long-term survival. Even though less than $25 \%$ of patients are initially eligible for liver surgery [3], liver metastases may become resectable after chemotherapy.

Nowadays, systemic treatments in metastastic CRC combine 2 or 3 drugs such as FOLFOX (fluorouracil, folinic acid, oxaliplatin), FOLFIRI (fluorouracil, folinic acid, irinote- 
can), or FOLFIRINOX (fluorouracil, folinic acid, oxaliplatin, and irinotecan) with targeted therapies (bevacizumab, cetuximab, or panitumumab) depending on the RAS status [4-7]. Studies report a correlation between response rate and secondary resection rate [4-7]. Nevertheless, $30-40 \%$ of RAS-wt patients are non-responders to anti-EGFR treatments [8]. Moreover, long-term toxicity for systemic treatment may be observed [9]. For RAS mutated tumors (Kras or Nras), which represent about $50-60 \%$ of CRC patients, available treatment lines are very limited.

Intra-arterial (IA) therapies have been developed for a long time to treat liver metastases [10-14]. Different IA approaches were proposed: hepatic arterial infusion of chemotherapy (HAIC), chemoembolization with lipiodol (conventional trans-arterial chemoembolization or c-TACE), and drug-eluting beads trans-arterial chemoembolization (DEBTACE) [14]. All these techniques take advantage of the $99 \%$ arterial blood supply of liver tumors, whereas the non-tumoral parenchyma is mainly supplied by the portal vein. Consequently, high drug concentrations can be achieved within the tumor while limiting systemic exposure and subsequent side effects. IA therapies could act as salvage treatments in unresectable patients with insufficient response rates following standard IV regimens, and especially in RAS-mutated patients for whom the number of treatment lines is very limited.

Among IA techniques, HAIC has been the most widely investigated in CRLM, based on two different regimens: FUDR-based [15] or oxaliplatin-based [16,17] IA infusion. Despite an attractive rationale and promising response rates $[18,19]$, a benefit in overall survival (OS) has never been demonstrated so far [19-22]. Technical difficulties with implanted pumps (for FUDR) or with the implantation of IA catheters have certainly impaired the efficacy of these approaches and strongly limited their widespread use [23,24].

Other IA techniques are easier to implement in routine clinical practice, but efforts should be made to optimize the treatment regimen. Surprisingly, drugs used for IA therapies vary a lot [25].

However, to our knowledge, drug selection has never been based on any cytotoxicity screening in CRC cell lines. Yet, it might be useless to reach higher intra-tumoral concentration thanks to IA injection if the drug is ineffective against the tumor cells. Varela et al. studied doxorubicin pharmacokinetics (PK) after intra-arterial treatment of hepatocellular carcinoma (HCC) [26] and showed that the peak drug concentration in serum was reached within 5 min after injection for both techniques, followed by a decrease in systemic release only 20 to $40 \mathrm{~min}$ after injection [26]. This led Boulin et al. to screen anticancer drugs on HCC cell lines after a short exposure time $(30 \mathrm{~min}$ ) to optimize drug selection for IA treatment [27]. They tested 11 drugs in vitro on 3 different cell lines and showed that the most frequently-used drug for TACE in HCC (i.e., doxorubicin) was not the best candidate compared with idarubicin, which displayed the greatest cytotoxicity profile [27]. The same group conducted further clinical studies showing promising results with idarubicin [28-31].

The present study aimed to screen drugs (currently or not currently used on CRC) on a panel of CRC cell lines with a short exposure time (30 min), in order to select the most efficient one to design further clinical trials of IA treatments for CRLM. The assessment of drug mechanism was however outside the scope of this study.

\section{Results}

2.1. Viability Curves for 12 Tested Cytotoxic Agents on 6 CRC Cell Lines (HCT116, HT29, Caco-2, SW48, SW480 and SW620)

\subsubsection{Topoisomerase II Inhibitor (Doxorubicin, Epirubicin and Idarubicin)}

Topoisomerase II inhibitors had a strong effect over SW620. Regarding doxorubicin and epirubicin, Caco-2, HCT116 and HT29 (at high concentrations for the latter) were the most resistant cell lines (Figure 1a,b). With doxorubicin and epirubicin, after 4 dilutions, a dose-effect was observed. Even at low concentrations, idarubicin had a strong effect, particularly over SW48 and SW620 (Figure 1c). No cell line exhibited any major resistance to idarubicin, except at very low concentrations for Caco-2 and SW480. For these 2 cell lines, we observed that $10 \%$ of cell viability was achieved after 7 dilutions of idarubicin 
(Figure 1c). With idarubicin, a moderate rebound effect occurred after 6 dilutions in most of the cell lines. For doxorubicin, epirubicin, and idarubicin, the viability curves of the cell line derived from the primary tumor (SW480) and metastasis of which (SW620) had quite a similar response profile.

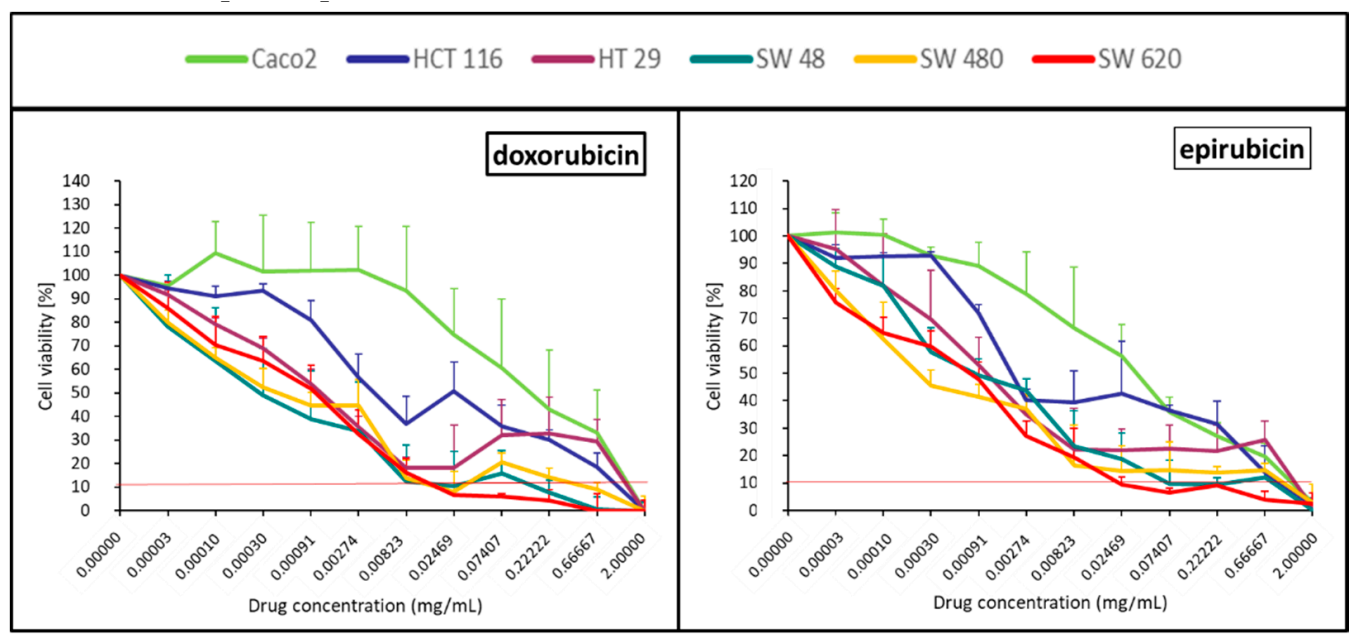

(a)

(b)

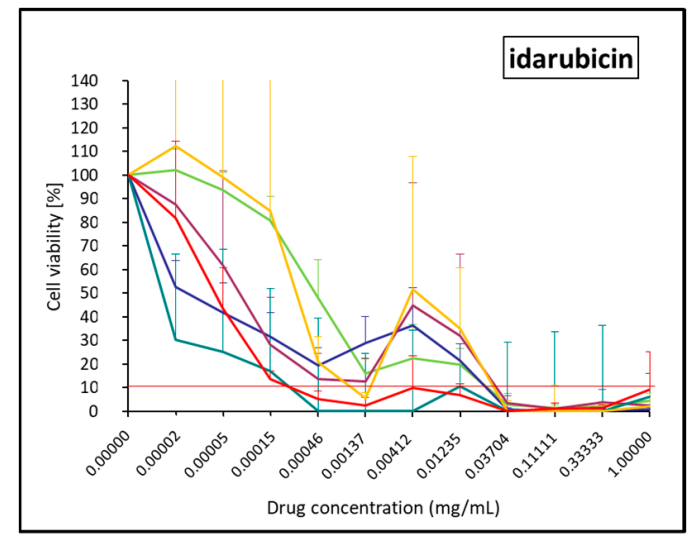

(c)

Figure 1. Colorectal cancer cell line viability curves (mean \pm standard deviation) after a $30 \mathrm{~min}$ contact time with the 3 anthracyclines: doxorubicin (a), epirubicin (b), and idarubicin (c). The horizontal red line represents $10 \%$ of cell viability. The results are presented after normalization with the control cells (untreated condition).

\subsubsection{Anti-Metabolites Effect (5-FU, Raltitrexed and Gemcitabine)}

Regarding 5-FU, HCT116 and Caco-2 were quickly resistant (Figure 2a). Compared with raltitrexed and gemcitabine, 5-FU was the most efficient over HT29, SW48, SW480, and SW620. With raltitrexed, cell viability is lowered to $10 \%$ only when it is used at maximum concentration (Figure 2b). Gemcitabine was mainly efficient over SW620 and SW48 (Figure 2c). A large plateau effect was observed with raltitrexed and gemcitabine for most of the tested concentrations (Figure $2 b, c)$ and the cytotoxicity profile of these two drugs strongly differed from one cell line to another (Figure $2 b, c)$. Caco-2 was the most resistant cell line with raltitrexed and gemcitabine (Figure $2 b, c$ ). 


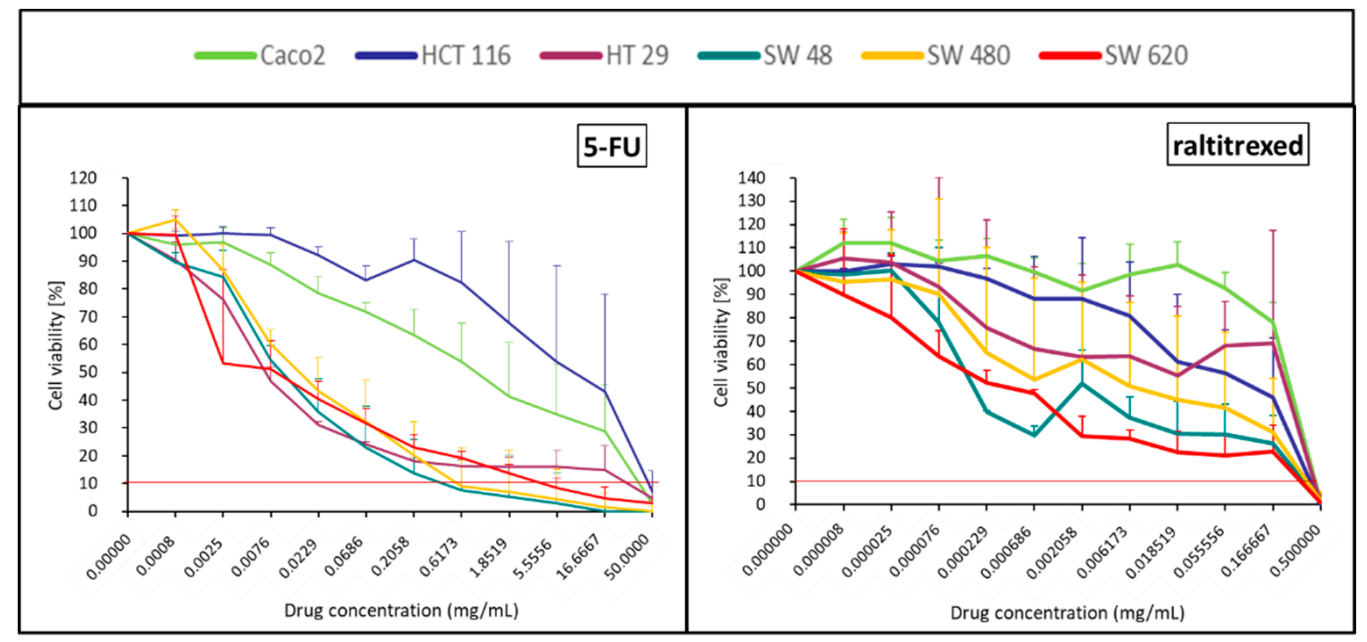

(a)

(b)

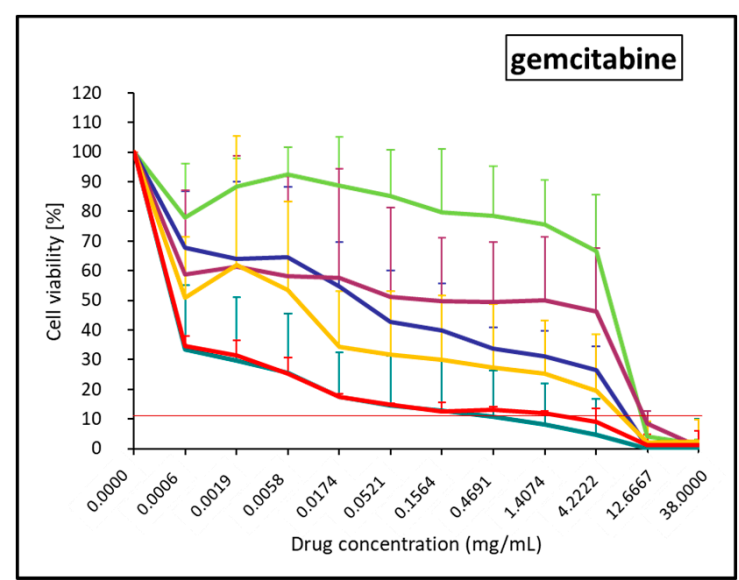

(c)

Figure 2. Colorectal cancer cell line viability curves (mean \pm standard deviation) after a $30 \mathrm{~min}$ contact time with the 3 anti-metabolites: 5-FU (a), raltitrexed (b), and gemcitabine (c). The horizontal red line represents $10 \%$ of cell viability. The results are presented after normalization with the control cells (untreated condition).

\subsubsection{Platinum Derivatives (Cisplatin and Oxaliplatin)}

A dose-effect relationship was strongly and quickly observed with cisplatin and oxaliplatin (Figure 3). With cisplatin, cell viability under $10 \%$ was only observed at Cmax and only in 2 cell lines (SW48 and SW620). Oxaliplatin quickly had no effect on HCT116 (Figure 3b). 


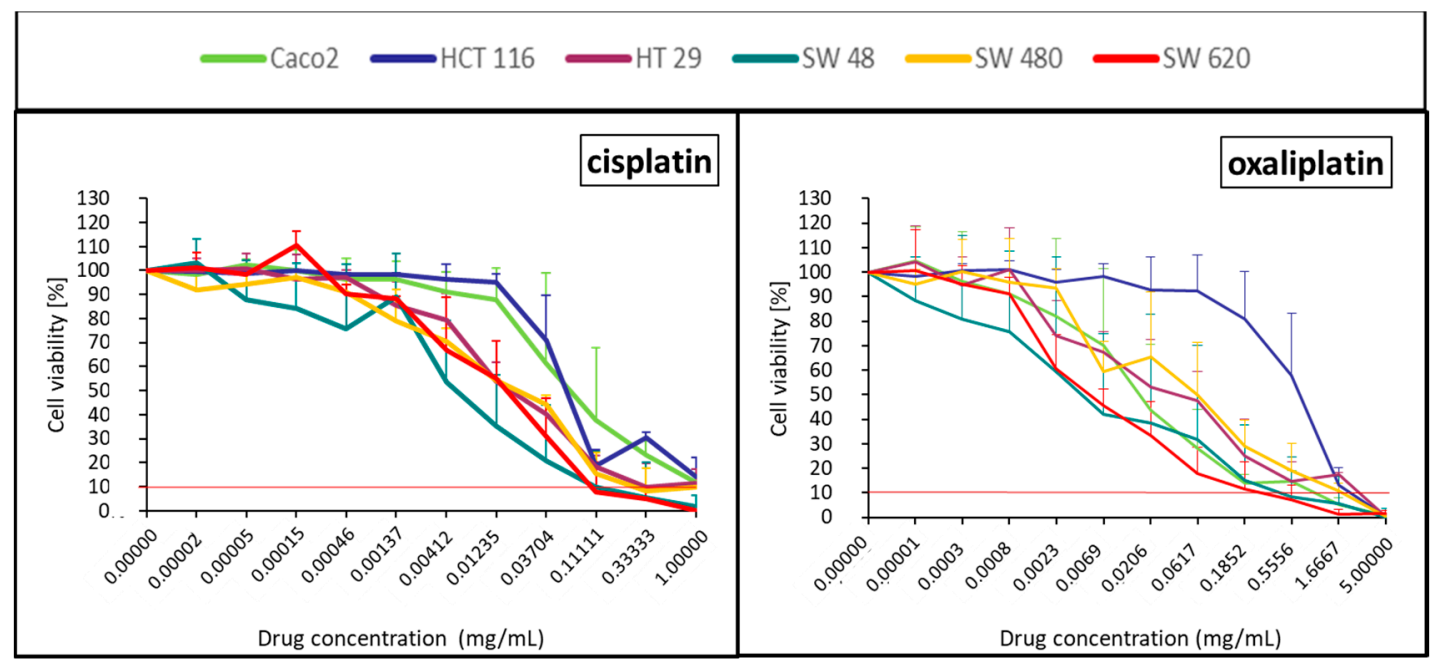

(a)

(b)

Figure 3. Colorectal cancer cell line viability curves (mean \pm standard deviation) after a 30 min contact time with the 2 platinum derivatives: cisplatin (a) and oxaliplatin (b). The horizontal red line represents $10 \%$ of cell viability. The results are presented after normalization with the control cells (untreated condition).

\subsubsection{Alkylating Antibiotic (Mitomycin C)}

The alkylating antibiotic, mitomycin C, led to more than $90 \%$ of cell death from the first 3 dilutions for SW48, SW480, SW620, and HT29 (Figure 4). HCT 116 and Caco-2 displayed resistant profiles.
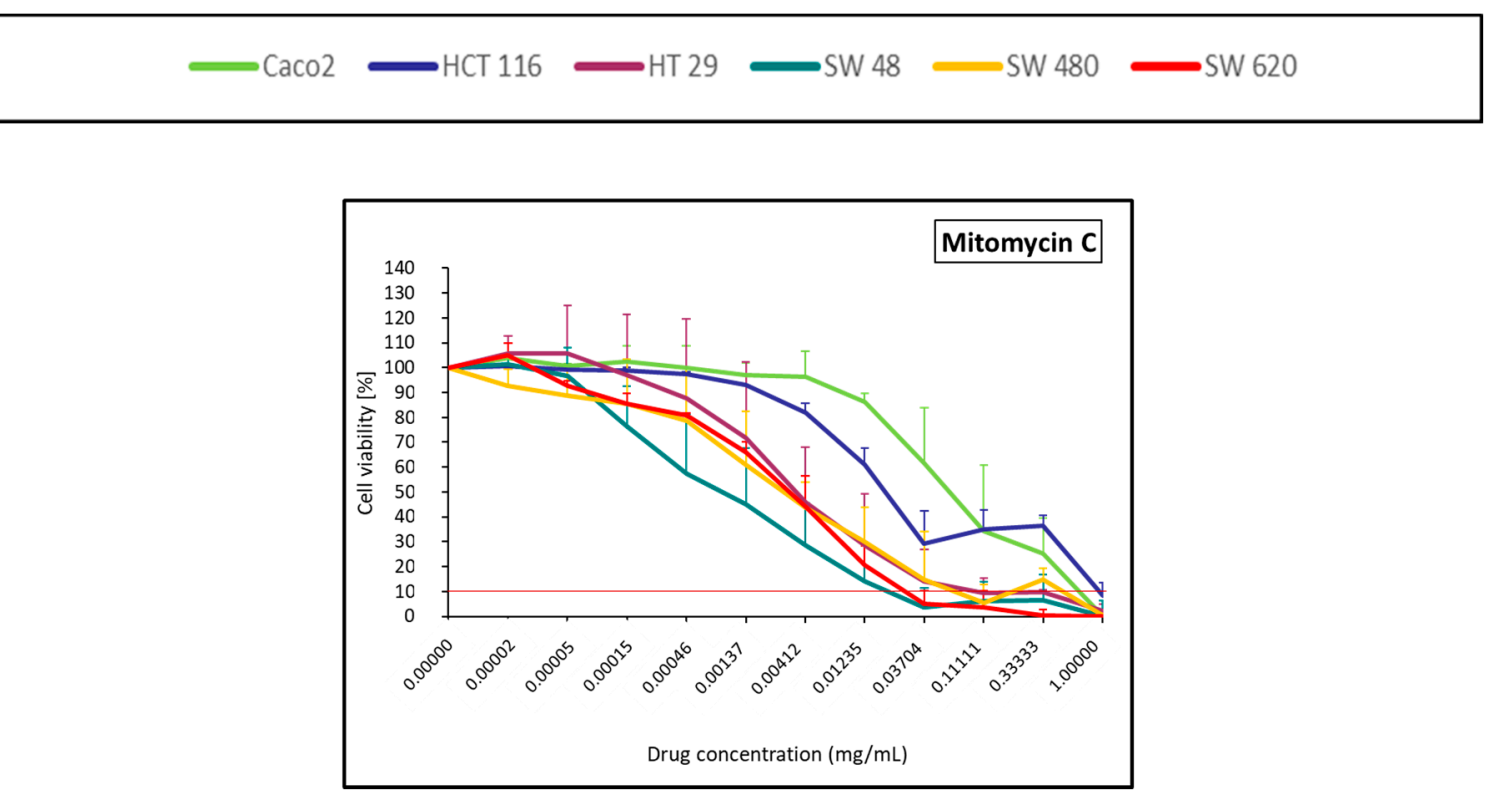

Figure 4. Colorectal cancer cell line viability curves (mean \pm standard deviation) after a 30 min contact time with an alkylating antibiotic (mitomycin C). The horizontal red line represents $10 \%$ of cell viability. The results are presented after normalization with the control cells (untreated condition).

\subsubsection{DNA Topoisomerase I Inhibitor (Irinotecan)}

Irinotecan led to $90 \%$ of cell death at high concentrations (Figure 5), but was no longer cytotoxic from the fourth dilution, whatever the cell line (Figure 5). 

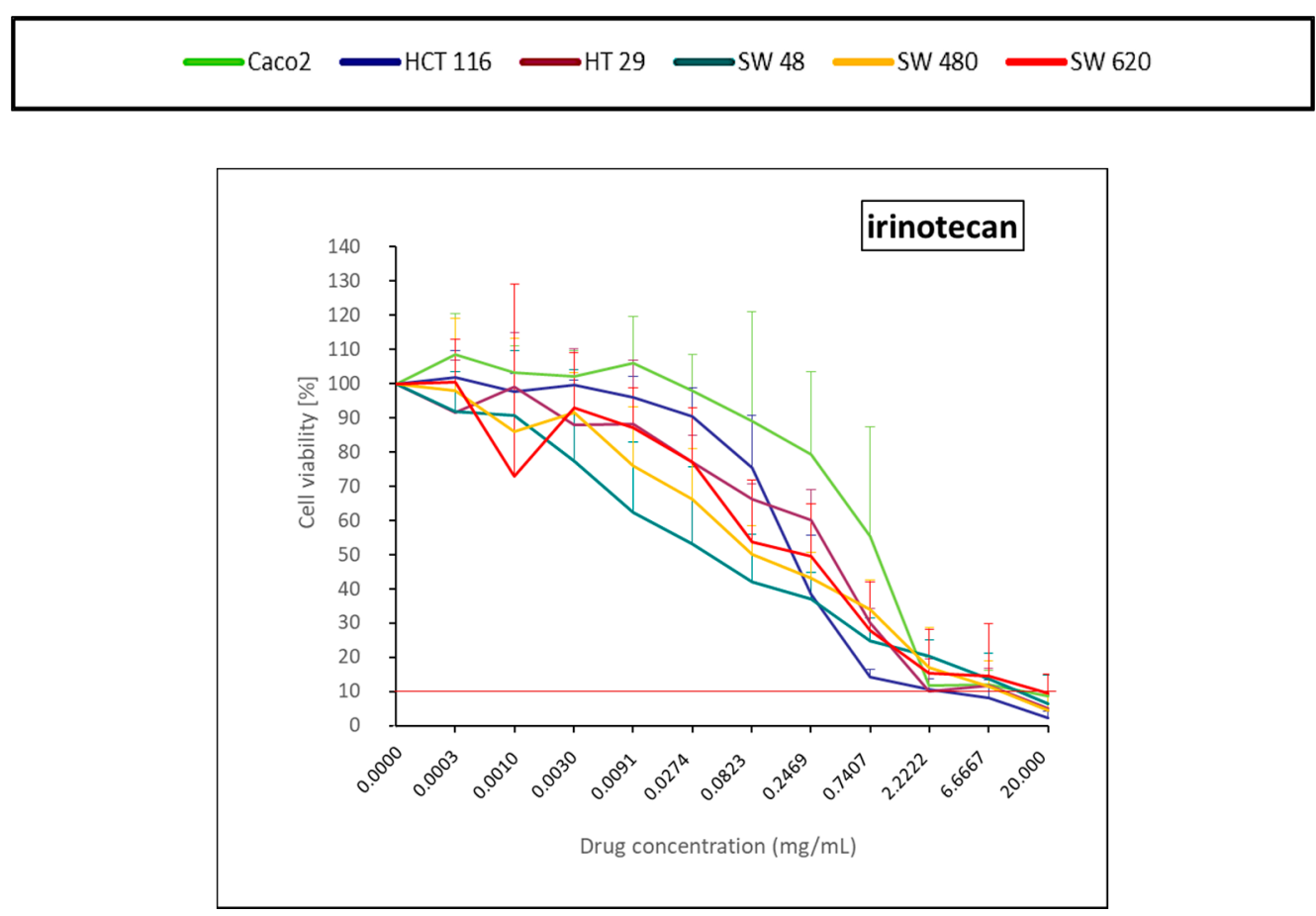

Figure 5. Colorectal cancer cell line viability curves (mean \pm standard deviation) after a 30 min contact time with a DNA topoisomerase inhibitor (irinotecan). The horizontal red line represents $10 \%$ of cell viability. The results are presented after normalization with the control cells (untreated condition).

\subsubsection{Antitumoral Antibiotic (Streptozocin)}

The antitumoral antibiotic, streptozocin, had almost no cytotoxicity effect, except at Cmax and at the first dilution (Figure 6).

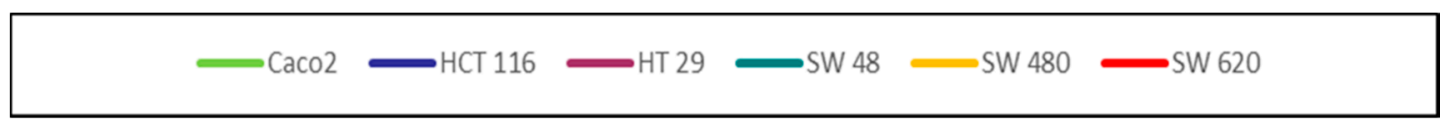

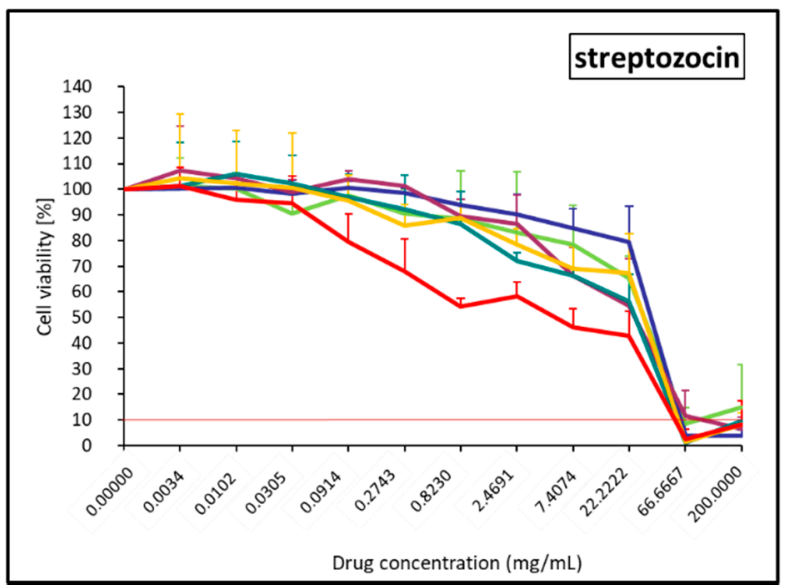

Figure 6. Colorectal cancer cell line viability curves (mean \pm standard deviation) after a 30 min contact time with an antitumoral antibiotic (streptozocin). The horizontal red line represents $10 \%$ of cell viability. The results are presented after normalization with the control cells (untreated condition). 


\subsubsection{Taxane (Paclitaxel)}

The cell viability curve of taxane (paclitaxel) (Figure 7) showed a cell proliferation for intermediate concentration.
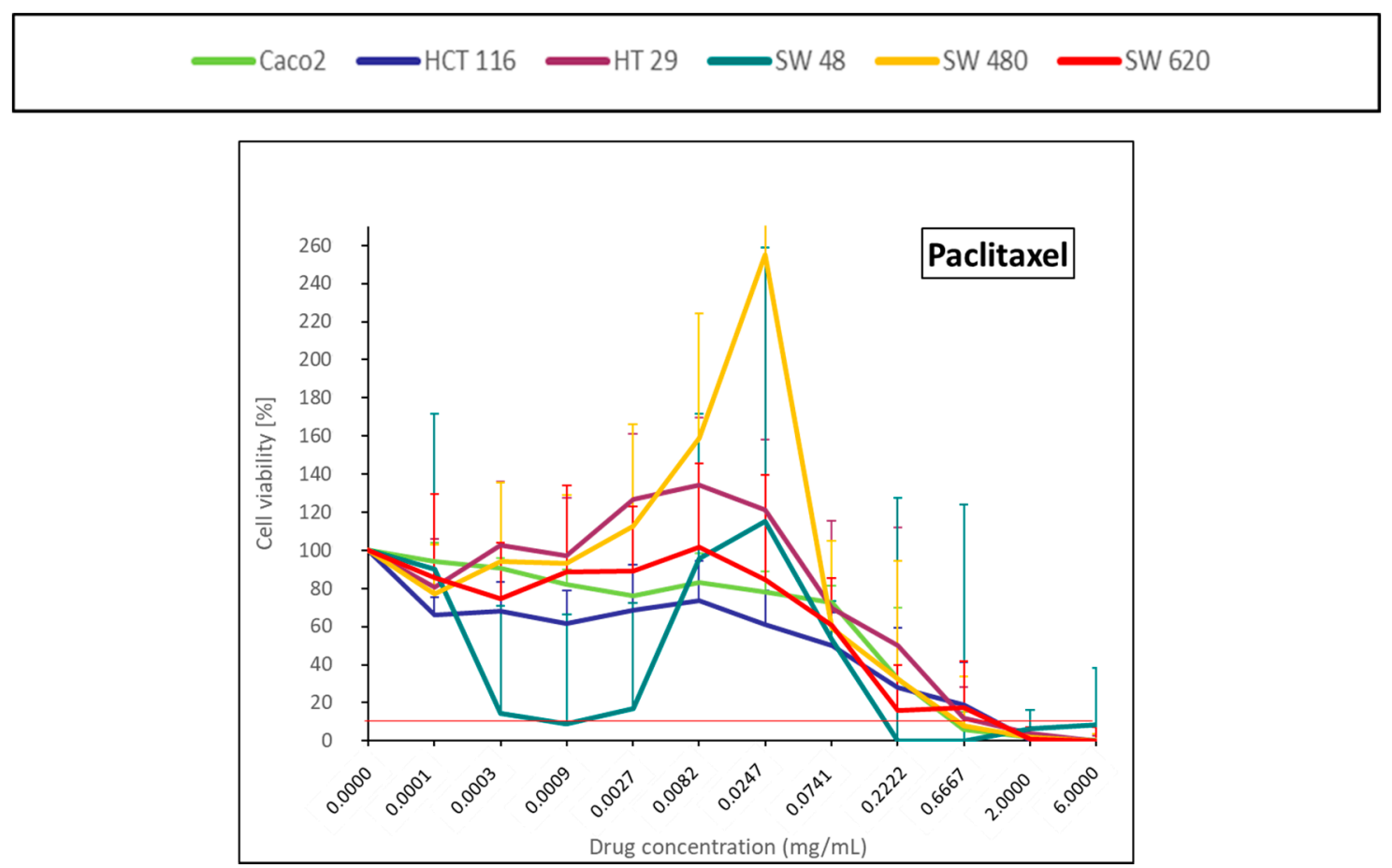

Figure 7. Colorectal cancer cell lines viability curves (mean \pm standard deviation) after a 30-min contact time with a taxane (paclitaxel). The horizontal red line represents $10 \%$ of cell viability. The results are presented after normalization with the control cells (untreated condition).

The statistical analysis (Anova and post-hoc test (LSD-Fisher)) compared cell viability for each drug; control versus any concentration is available in Supplementary Table S1.

\subsection{IC $C_{50}, I_{90}$ and Cytotoxicity Index (CyI90) for Each CRC Cell Line According the 12 Antitumoral Agents}

The cytotoxic agent concentrations inducing $50 \%$ and $90 \%$ of cell death $\mathrm{IC}_{50}$ and $\mathrm{IC}_{90}$, respectively) are represented in Tables 1 and 2. Idarubicin is the cytotoxic agent with the lowest $\mathrm{IC}_{50}$ and $\mathrm{IC}_{90}$.

Table 1. $\mathrm{IC}_{50}$ values (mean \pm standard deviation) obtained for 6 colorectal cancer cell lines and 12 antitumoral agents. The bold is to underline the name of the drug, distinguish from the family of the drug.

\begin{tabular}{|c|c|c|c|c|c|c|}
\hline $\begin{array}{ll} & \text { Cell Line } \\
\end{array}$ & Caco-2 & НCT116 & HT29 & SW48 & SW480 & SW620 \\
\hline $\begin{array}{c}\text { Topoisomerase II inhibitor } \\
\text { doxorubicin }\end{array}$ & $0.22 \pm 0.28$ & $0.01 \pm 0.01$ & $0.001 \pm 0.001$ & $\begin{array}{c}0.0007 \pm \\
0.0006\end{array}$ & $\begin{array}{c}0.0006 \pm \\
0.0003\end{array}$ & $\begin{array}{c}0.0008 \pm \\
0.0007\end{array}$ \\
\hline $\begin{array}{c}\text { Topoisomerase II inhibitor } \\
\text { epirubicin }\end{array}$ & $0.03 \pm 0.02$ & $0.01 \pm 0.01$ & $0.001 \pm 0.001$ & $\begin{array}{c}0.0007 \pm \\
0.0001\end{array}$ & $\begin{array}{c}0.0003 \pm \\
0.0002\end{array}$ & $\begin{array}{c}0.0005 \pm \\
0.0002\end{array}$ \\
\hline $\begin{array}{c}\text { Topoisomerase II inhibitor } \\
\text { idarubicin }\end{array}$ & $\begin{array}{c}0.0004 \pm \\
0.0001\end{array}$ & $\begin{array}{c}0.00005 \pm \\
0.00006\end{array}$ & $\begin{array}{c}0.00003 \pm \\
0.00002\end{array}$ & $\begin{array}{c}0.00002 \pm \\
0.00001\end{array}$ & $\begin{array}{c}0.00007 \pm \\
0.00009\end{array}$ & $\begin{array}{c}0.00003 \pm \\
0.00002\end{array}$ \\
\hline $\begin{array}{l}\text { Anti-metabolites } \\
\text { 5-FU }\end{array}$ & $0.47 \pm 0.08$ & $\begin{array}{c}213.75 \pm \\
345.11\end{array}$ & $0.007 \pm 0.001$ & $0.01 \pm 0.005$ & $0.02 \pm 0.01$ & $0.01 \pm 0.009$ \\
\hline $\begin{array}{l}\text { Anti-metabolites } \\
\text { raltitrexed }\end{array}$ & $0.25 \pm 0.07$ & $0.08 \pm 0.08$ & $0.12 \pm 0.22$ & $0.10 \pm 0.17$ & $0.05 \pm 0.08$ & $\begin{array}{c}0.0002 \pm \\
0.0002\end{array}$ \\
\hline
\end{tabular}


Table 1. Cont.

\begin{tabular}{|c|c|c|c|c|c|c|}
\hline $\begin{array}{ll}\text { Drug } & \text { Cell Line } \\
\end{array}$ & Caco-2 & HCT116 & HT29 & SW48 & SW480 & SW620 \\
\hline $\begin{array}{l}\text { Anti-metabolites } \\
\text { gemcitabin }\end{array}$ & $3.03 \pm 2.21$ & $0.09 \pm 0.15$ & $0.79 \pm 1.36$ & $\begin{array}{c}0.0004 \pm \\
0.0006\end{array}$ & $0.05 \pm 0.09$ & $\begin{array}{c}0.0001 \pm \\
0.00005\end{array}$ \\
\hline $\begin{array}{c}\text { Platinum derivatives } \\
\text { cisplatin }\end{array}$ & $0.09 \pm 0.10$ & $0.14 \pm 0.03$ & $0.01 \pm 0.005$ & $0.01 \pm 0.01$ & $0.01 \pm 0.003$ & $0.01 \pm 0.007$ \\
\hline $\begin{array}{c}\text { Platinum derivatives } \\
\text { oxaliplatin }\end{array}$ & $0.02 \pm 0.01$ & $0.61 \pm 00.39$ & $0.04 \pm 0.04$ & $0.04 \pm 0.06$ & $0.07 \pm 0.06$ & $0.008 \pm 0.005$ \\
\hline $\begin{array}{l}\text { Alkylating antibiotic } \\
\text { mitomycin C }\end{array}$ & $0.08 \pm 0.08$ & $0.02 \pm 0.01$ & $0.005 \pm 0.007$ & $\begin{array}{c}0.001 \pm \\
0.0008\end{array}$ & $0.004 \pm 0.005$ & $\begin{array}{c}0.002 \pm \\
0.0007\end{array}$ \\
\hline $\begin{array}{l}\text { Topoisomerase I inhibitor } \\
\text { irinotecan }\end{array}$ & $0.95 \pm 0.83$ & $0.20 \pm 0.13$ & $0.20 \pm 0.05$ & $0.07 \pm 0.09$ & $0.12 \pm 0.10$ & $0.18 \pm 0.10$ \\
\hline $\begin{array}{l}\text { Antitumoral antibiotic } \\
\text { streptozocin }\end{array}$ & $22.93 \pm 10.86$ & $24.58 \pm 1.33$ & $19.31 \pm 10.15$ & $13.88 \pm 3.21$ & $18.09 \pm 4.77$ & $2.65 \pm 1.12$ \\
\hline $\begin{array}{c}\text { Taxane } \\
\text { paclitaxel }\end{array}$ & $0.10 \pm 0.03$ & $0.05 \pm 0.09$ & $0.25 \pm 0.19$ & $\begin{array}{c}0.0006 \pm \\
0.0009\end{array}$ & $0.16 \pm 0.22$ & $0.05 \pm 0.05$ \\
\hline
\end{tabular}

Table 2. $\mathrm{IC}_{90}$ values (mean \pm standard deviation) obtained for the 6 colorectal cancer cell lines and the 12 antitumoral agents. The bold is to underline the name of the drug, distinguish from the family of the drug.

\begin{tabular}{|c|c|c|c|c|c|c|}
\hline $\begin{array}{ll} & \text { Cell Line } \\
\end{array}$ & Caco-2 & НСТ116 & HT29 & SW48 & SW480 & SW620 \\
\hline $\begin{array}{c}\text { Topoisomerase II inhibitor } \\
\text { doxorubicin }\end{array}$ & $2.68 \pm 2.02$ & $5.40 \pm 4.77$ & $1.47 \pm 1.47$ & $0.07 \pm 0.10$ & $0.13 \pm 0.08$ & $0.02 \pm 0.009$ \\
\hline $\begin{array}{c}\text { Topoisomerase II inhibitor } \\
\text { epirubicin }\end{array}$ & $1.55 \pm 0.93$ & $4.16 \pm 4.07$ & na & $0.10 \pm 0.02$ & $0.43 \pm 0.36$ & $0.04 \pm 0.03$ \\
\hline $\begin{array}{c}\text { Topoisomerase II inhibitor } \\
\text { idarubicin }\end{array}$ & $0.009 \pm 0.007$ & $0.04 \pm 0.04$ & $\begin{array}{c}0.0005 \pm \\
0.0003\end{array}$ & $0.002 \pm 0.001$ & $0.002 \pm 0.001$ & $\begin{array}{c}0.0003 \pm \\
0.0001\end{array}$ \\
\hline $\begin{array}{l}\text { Anti-metabolites } \\
\text { 5-FU }\end{array}$ & $\begin{array}{c}138.28 \pm \\
193.78\end{array}$ & $\begin{array}{c}82,843.1 \pm \\
103,130.2\end{array}$ & $1.31 \pm$ na & $2.97 \pm 4.74$ & $1.92 \pm 2.75$ & $1.77 \pm 0.27$ \\
\hline $\begin{array}{l}\text { Anti-metabolites } \\
\text { raltitrexed }\end{array}$ & $\begin{array}{c}260.88 \pm \\
36.32\end{array}$ & $\begin{array}{c}221.28 \pm \\
12.01\end{array}$ & $\begin{array}{c}173.89 \pm \\
91.41\end{array}$ & $\begin{array}{c}181.32 \pm \\
20.44\end{array}$ & $202.82 \pm 8.82$ & $\begin{array}{c}538.65 \pm \\
437.50\end{array}$ \\
\hline $\begin{array}{l}\text { Anti-metabolites } \\
\text { gemcitabin }\end{array}$ & $\begin{array}{c}202.35 \pm \\
284.002\end{array}$ & $55.87 \pm 37.11$ & $\begin{array}{l}9832.8 \pm \\
13,788.9\end{array}$ & $3.87 \pm 4.36$ & $\begin{array}{c}77.70 \pm \\
110.10\end{array}$ & $0.74 \pm 0.40$ \\
\hline $\begin{array}{l}\text { Platinum derivatives } \\
\text { cisplatin }\end{array}$ & $2.81 \pm 2.47$ & $2.53 \pm 2.03$ & $3.34 \pm 4.26$ & $00.50 \pm 0.79$ & $0.87 \pm 0.68$ & $0.20 \pm 0.11$ \\
\hline $\begin{array}{c}\text { Platinum derivatives } \\
\text { oxaliplatin }\end{array}$ & $0.40 \pm 0.23$ & $5.57 \pm 3.59$ & $2.24 \pm 1.64$ & $0.83 \pm 1.20$ & $1.34 \pm 0.79$ & $0.26 \pm 0.26$ \\
\hline $\begin{array}{l}\text { Alkylating antibiotic } \\
\text { mitomycin C }\end{array}$ & $0.80 \pm 0.76$ & $0.45 \pm \mathrm{Na}$ & $0.08 \pm 0.08$ & $0.04 \pm 0.05$ & $0.13 \pm 0.14$ & $0.04 \pm 0.03$ \\
\hline $\begin{array}{l}\text { Topoisomerase I inhibitor } \\
\text { irinotecan }\end{array}$ & $8.91 \pm 7.10$ & $2.39 \pm 0.86$ & $13.64 \pm 10.02$ & $15.34 \pm 11.25$ & $11.28 \pm 5.57$ & $19.77 \pm 27.26$ \\
\hline $\begin{array}{l}\text { Antitumoral antibiotic } \\
\text { streptozocin }\end{array}$ & $20.70 \pm 0.54$ & $0.88 \pm 0.57$ & $20.03 \pm 10.35$ & $10.31 \pm 10.33$ & $0.66 \pm 0.64$ & $0.20 \pm 0.15$ \\
\hline $\begin{array}{c}\text { Taxane } \\
\text { paclitaxel }\end{array}$ & $1.99 \pm 1.72$ & $3.02 \pm 2.60$ & $1.73 \pm 1.79$ & $\begin{array}{c}585.43 \pm \\
1011.63\end{array}$ & $1.56 \pm 1.98$ & $41.65 \pm 50.47$ \\
\hline
\end{tabular}

To compare the effect of the different agents over the studied cell lines, the cytotoxic index $\left(\mathrm{CyI}_{90}\right)$ was determined for each agent and cell line by calculating the ratio of maximal concentration to $\mathrm{IC}_{90}$. The values are represented in Table 3 . The highest value of 
$\mathrm{CyI}_{90}$ was obtained by idarubicin for all the studied cell lines, except for SW48, over which gemcitabine had the highest $\mathrm{CyI}_{90}$ (Table 3).

Table 3. Cytotoxic Index $\left(\mathrm{CyI}_{90}\right)$ values (mean \pm standard deviation) obtained for the 6 colorectal cancer cell lines and the 12 antitumoral agents. The bold is to underline the name of the drug, distinguish from the family of the drug. Numbers in bold are the highest values for each column (cell line type).

\begin{tabular}{|c|c|c|c|c|c|c|}
\hline $\begin{array}{ll} & \text { Cell Line } \\
\end{array}$ & Caco-2 & НСТ116 & НТ29 & SW48 & SW480 & SW620 \\
\hline $\begin{array}{c}\text { Topoisomerase II inhibitor } \\
\text { doxorubicin }\end{array}$ & $1.13 \pm 0.84$ & $0.76 \pm 0.79$ & $2.72 \pm 2.72$ & $\begin{array}{c}359.57 \pm \\
556.29\end{array}$ & $25.30 \pm 25.53$ & $96.25 \pm 31.85$ \\
\hline $\begin{array}{c}\text { Topoisomerase II inhibitor } \\
\text { epirubicin }\end{array}$ & $1.58 \pm 0.74$ & $0.92 \pm 0.90$ & na \pm na & $19.90 \pm 4.08$ & $7.25 \pm 6.19$ & $61.78 \pm 35.10$ \\
\hline $\begin{array}{c}\text { Topoisomerase II inhibitor } \\
\text { idarubicin }\end{array}$ & $\begin{array}{c}156.97 \pm \\
114.03\end{array}$ & $83.32 \pm 99.27$ & $\begin{array}{l}2170.84 \pm \\
993.71\end{array}$ & $\begin{array}{c}468.19 \pm \\
223.29\end{array}$ & $\begin{array}{c}479.79 \pm \\
235.56\end{array}$ & $\begin{array}{l}3168.35 \pm \\
1567.32\end{array}$ \\
\hline $\begin{array}{l}\text { Anti-metabolites } \\
\text { 5-FU }\end{array}$ & $1.37 \pm 1.14$ & $0.94 \pm 1.26$ & $37.92 \pm$ na & $\begin{array}{c}276.55 \pm \\
368.76\end{array}$ & $\begin{array}{c}191.74 \pm \\
250.78\end{array}$ & $28.53 \pm 4.47$ \\
\hline $\begin{array}{l}\text { Anti-metabolites } \\
\text { raltitrexed }\end{array}$ & $0.19 \pm 0.04$ & $0.72 \pm 0.37$ & $0.36 \pm 0.27$ & $1.01 \pm 1.14$ & $1.31 \pm 0.93$ & $4.45 \pm 4.48$ \\
\hline $\begin{array}{l}\text { Anti-metabolites } \\
\text { gemcitabin }\end{array}$ & $0.70 \pm 0.56$ & $0.86 \pm 0.42$ & $0.23 \pm 0.32$ & $\begin{array}{c}18,126.37 \pm \\
31,381.13\end{array}$ & $\begin{array}{c}252.01 \pm \\
435.20\end{array}$ & $71.45 \pm 56.09$ \\
\hline $\begin{array}{l}\text { Platinum derivatives } \\
\text { cisplatin }\end{array}$ & $0.62 \pm 0.50$ & $0.56 \pm 0.31$ & $1.59 \pm 2.02$ & $15.46 \pm 14.33$ & $1.59 \pm 0.86$ & $6.45 \pm 4.15$ \\
\hline $\begin{array}{l}\text { Platinum derivatives } \\
\text { oxaliplatin }\end{array}$ & $14.78 \pm 6.91$ & $1.30 \pm 1.00$ & $4.36 \pm 4.62$ & $\begin{array}{c}658.91 \pm \\
1124.13\end{array}$ & $5.67 \pm 5.01$ & $45.61 \pm 47.78$ \\
\hline $\begin{array}{l}\text { Alkylating antibiotic } \\
\text { mitomycin C }\end{array}$ & $2.00 \pm 1.24$ & $2.18 \pm$ na & $19.86 \pm 12.45$ & $\begin{array}{c}125.52 \pm \\
203.90\end{array}$ & $13.60 \pm 9.02$ & $34.54 \pm 20.12$ \\
\hline $\begin{array}{c}\text { Topoisomerase I inhibitor } \\
\text { irinotecan }\end{array}$ & $3.60 \pm 2.84$ & $9.12 \pm 3.31$ & $2.83 \pm 2.98$ & $1.78 \pm 1.31$ & $2.15 \pm 1.20$ & $3.68 \pm 3.18$ \\
\hline $\begin{array}{l}\text { Antitumoral antibiotic } \\
\text { streptozocin }\end{array}$ & $0.77 \pm 0.11$ & $0.91 \pm 0.05$ & $1.49 \pm 1.00$ & $1.11 \pm 0.13$ & $0.99 \pm 0.04$ & $0.55 \pm 0.45$ \\
\hline $\begin{array}{l}\text { Taxane } \\
\text { paclitaxel }\end{array}$ & $5.12 \pm 3.54$ & $5.77 \pm 7.37$ & $6.76 \pm 5.18$ & $7.68 \pm 11.24$ & $30.66 \pm 48.10$ & $3.84 \pm 4.66$ \\
\hline
\end{tabular}

For the $\mathrm{CyI}_{90}$ results presented in Figure 8, we reported the $p$-value of the one-way ANOVA (drug effect) for each cell lines. Idarubicin stood out as the anticancer-drug with the most significant different $\mathrm{CyI}_{90}$ in comparison with the other cytotoxic agents over Caco-2 $(p<0.001)$, HT29 $(p<0.001)$, SW480 $(p=0.020)$, and SW $620(p<0.001)$ (Figure 8a-d). For HCT 116, there was a trend for idarubicin to be the best candidate $(p=0.140)$ (Figure 8e). Gemcitabine had the highest $\mathrm{CyI}_{90}$ value for $\mathrm{SW} 48$, but without a significant difference $(p=0.490)$ (Figure $8 \mathrm{f}$ ). The significant $p$-values of the post-hoc tests (LSD Fisher) were reported directly in Figure 8. 


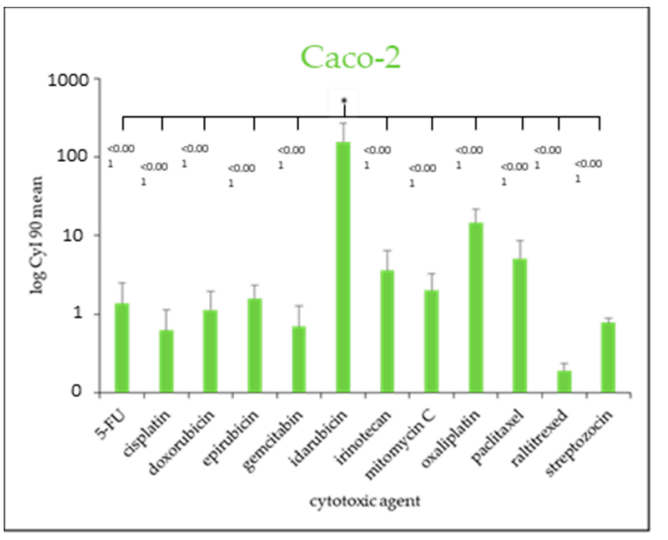

(a)

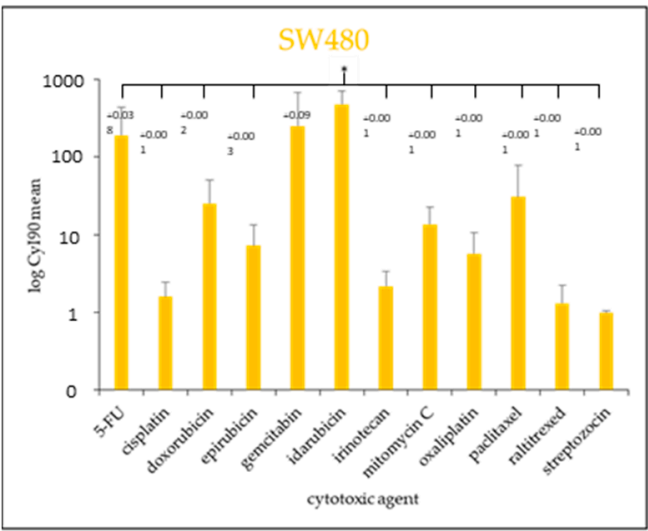

(c)

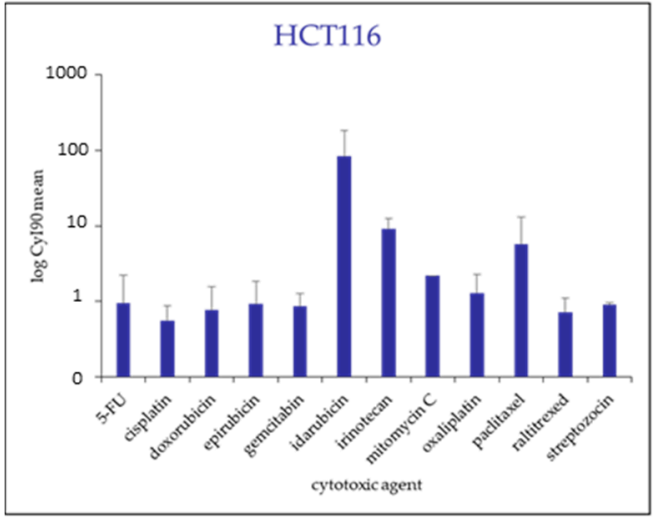

(e)

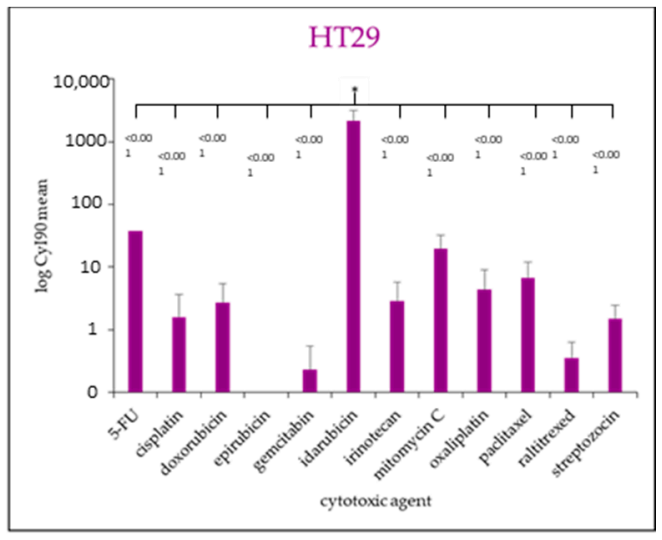

(b)

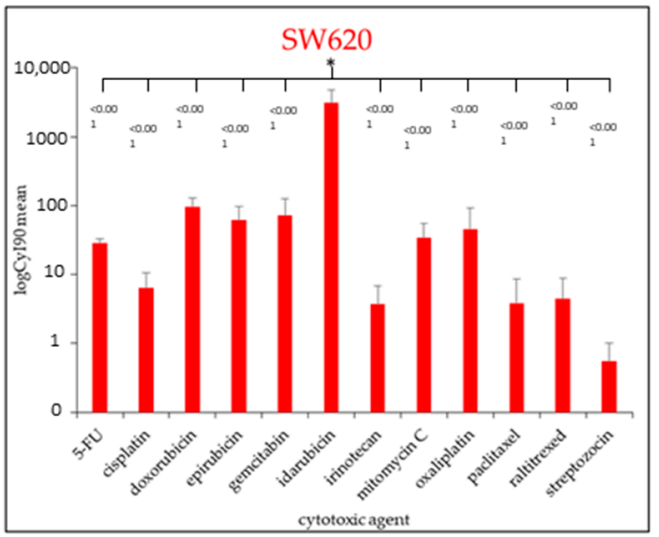

(d)

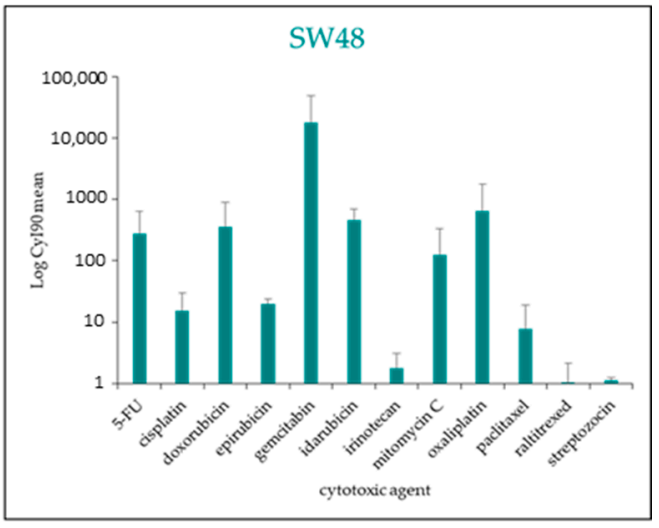

Figure 8. Bar plot representation of the cytotoxic indexes (mean \pm standard deviation) for the 6 colorectal cancer cell lines: Caco-2 (a), HT29 (b), SW480 (c), SW620 (d), HCT116 (e), SW48 (f). The significant $p$-values of the post-hoc tests (LSD Fisher) were reported for cell lines with significant one-way ANOVA $(p<0.05)$.

\section{Discussion}

Chemotherapeutic agents for IA treatment of CRLM are very heterogeneous. The rationale for drug choice has never been based on any cytotoxicity study. In the present study, we tested 12 anticancer drugs after short exposure time, in keeping with pharmacokinetics (PK) data observed during IA therapies [26], as suggested in other studies [27]. The main results of our study are that idarubicin emerged as the most cytotoxic agent to most of the studied CRC cell lines (Caco-2, HT29, HCT116, SW48, and SW480). Gemcitabine was the most efficient for SW48 (although statistically non-significant). Interestingly, the most commonly used cytotoxic agents in the systemic and intra-arterial treatment of CRLM (oxaliplatin, 5-FU, irinotecan) showed very limited cytotoxicity to all the tested cell lines. 
The biphasic curves for anthracyclines and the cell growth obtained with low dose of paclitaxel may need an additional study on the mechanisms of response. Nevertheless, according to our results, paclitaxel did not seem to be significant over the CRC cell lines.

Boulin et al., who used a similar methodology (cytotoxicity evaluation after a 30-min exposure time) on 3 HCC cell lines, also found idarubicin to be the best cytotoxic agent for TACE in HCC treatment [27]. Idarubicin is an anthracycline interacting with topoisomerase II and inhibiting the synthesis of nucleic acids. Modification on Position 4 on anthracycline hub gives a strong lipophilicity to idarubicin, which leads to strong intracellular penetration, better than that of other anthracyclines. If we focus on TACE, idarubicin pharmacokinetics with lipiodol were evaluated in-vitro and in-vivo [32]. The hepatic extraction ratio of idarubicin has not been reported in the literature so far. However, a $40 \%$ biodisponibility of idarubicin was published after intra-arterial administration of idarubicin-TACE, thereby suggesting a favorable extraction ratio [32]. Idarubicin has been widely explored for IA treatment, either combined with lipiodol [33] or with drug-eluting beads [29,31]. In addition to these chemotherapies, we also tested lipiodol, one of the available vectors for intra-arterial therapy. No significant effect of lipiodol was reported on CRC cell line viability (Supplementary data), which showed that this drug could definitely be regarded as a vector without any efficacy by itself. Phase I studies with IA idarubicin exhibited high toxicity profile in human patients with HCC. Therefore, in terms of feasibility, the use of idarubicin-based regimen for IA treatment should be even better tolerated in CRLM patients, who are most likely less fragile than cirrhotic patients.

Response to standard oncologic treatment is limited in CRC and there is a great potential to improve treatment efficacy by the molecularly-guided repurposing of targeted drugs. De facto, molecular classification of CRC has evolved in recent years, resulting in the four biologically distinct consensus molecular subtypes (CMS): CMS1 MSI (microsatellite instability)-immune, CMS2 epithelial and canonical, CMS3 epithelial and metabolic, and CMS4 mesenchymal [34]. The CMS classification has prognostic value independent of cancer stage, with dismal survival outcomes for the CMS4 population [35]. In the metastatic setting, patients with MSI tumors have a poor prognosis, but respond well to immune checkpoint inhibition [36]. A potential predictive value of the CMS groups was also suggested from retrospective analyses of clinical trials, including lack of benefit from oxaliplatin and anti-EGFR treatment $[35,37]$ in tumors with a mesenchymal-like phenotype, the latter being independent of RAS mutation status. However, increased understanding of the unique drug sensitivities of the individual CMS groups has great potential to advance precision medicine in colorectal cancer.

Caco-2, HCT 116, SW480, and SW620 belong to CMS 4 (i.e., the mesenchymal group), associated with the most aggressive disease and the worst survival. For all these CRC cell lines, idarubicin is the best candidate in our study. HT29 belongs to CMS 3, i.e., the metabolic group. Idarubicin is also the best candidate with a short exposure time. As for SW48 which is classified into CMS 1, i.e., an MSI-immune subtype, gemcitabine appears as the most interesting drug compared with other drugs. Our results are thus in line with those of Sveen et al. [38] who reported that the most efficient drugs for CMS1 and CMS4 cell lines were the inhibitors of topoisomerase II and of antimetabolite, especially idarubicin and gemcitabine [38]. In this substantial work, they also reported that idarubicin and gemcitabine had an effect over MSI+ cell lines. Again, our results were aligned with this study, despite the very short exposure time.

A comparison of the present results with the literature was carried out based on the few available studies. Three studies evaluated whether oxalipatin, irinotecan, and gemcitabine could have $\mathrm{IC}_{50}$ compatible with $\mathrm{CIAH}$ [39-41]. Only Hofmann et al. evaluated irinotecan efficacy on CRC cell lines with the same exposure time (30 min) [41]. Cytotoxicity evaluation used the HTCA (Human Tumor colony-forming assay). IC 50 on HT29 was $200 \mu \mathrm{g} / \mathrm{mL}$, which was similar to that obtained in the present study $(202 \pm 57 \mu \mathrm{g} / \mathrm{mL})$. Kornmann et al. studied in-vitro effect of oxaliplatin and gemcitabine with a 2-h, 4-h, and 24-h exposure time on CRC cell lines (HT29, NMG64/84 colon and COLO 357) and on 
fresh liver metastases [39]. The respective $\mathrm{IC}_{50}$ values for oxaliplatin and gemcitabine were $<10 \mu \mathrm{g} / \mathrm{mL}$ and $100 \mu \mathrm{g} / \mathrm{mL}$ after a 2-h exposure on HT29. In the present study, the $\mathrm{IC}_{50}$ values on HT29 after a 30-min exposure were $40.9 \pm 41 \mu \mathrm{g} / \mathrm{mL}$ for oxaliplatin and $793 \mu \mathrm{g} / \mathrm{mL}$ for gemcitabine, which clearly highlighted the time-dependent effect of these two drugs. A concentration dependence is also known for gemcitabine [42]. No study has evaluated the $\mathrm{IC}_{90}$ of cytotoxic agents over CRC cell lines. Yet, the stronger the cytotoxicity index, the higher the chance to find an effective agent for locoregional therapies. In addition, colorectal adenocarcinomas are supposed to be sensitive to anthracyclines and other topoisomerase II inhibitors. The Caco-2 resistance was well studied and related to two mechanisms: MDR (Multi Drug Resistance) system and a confluence-dependent resistance [43]. Our results showed a significant efficacy of idarubicin over Caco-2, which is possibly correlated with the known characteristics of idarubicin to overcome glycoprotein (PgP)-related MDR [44].

Some limitations to our study must be acknowledged. First, the cell viability analysis methodology was based on WST-1, which is a metabolic marker less sensitive than crystal violet (cell marker) used by Boulin et al. [27]. However, WST-1 was chosen because it could provide a fast and sensitive evaluation of cell viability and proliferation for the 9504 culture wells analyzed. Moreover, to ensure robust results, four replicates per experiment were relied upon with three independent experiments for each condition. Second, we did not test any CMS 2 cell line. Nevertheless Sveen et al. found poor sensitivity to chemotherapy and, on the contrary, extreme sensitivity to anti EGFR and HERB2 [38]. Interestingly, we tested both wild-type and mutated RAS cell lines and the efficacy of idarubicin appeared to be independent of RAS status. Third, in this drug screening study of cell lines, Sveen et al. identified CMS1 and CMS4 as potential predictive biomarkers for response to HSP90 inhibition. In vivo, this targeted treatment may alleviate chemoresistance in CMS4. Another point is related to the characteristics of the studied cell lines with respect to Duke's staging system. Only one tested cell line (HCT116) came from a Duke's stage D adenocarcinoma. Nevertheless, to our knowledge, there are only three cell lines coming from a Duke's stage D, i.e., with the ability to colonize the liver in clinical conditions. All these three cell lines are RAS-mutated, which explains why we only chose one.

Another perspective could be to test "combined chemotherapies".

According to our results, we plan to propose a phase II trial with idarubicin in MSI$\mathrm{mCRC}$ after failure of two systemic treatment lines.

\section{Materials and Methods}

\subsection{Cell Lines}

CRC is a heterogeneous disease mainly related to the heterogeneity of genomic instability. We chose different cell lines to represent the different molecular characteristics of CRC (BRAF and/or KRAS mutations, as well as BRAF/KRAS wt; Chromosomal Instability (CIN) or MicroSatellite Instability (MSI)) coming from primary or metastatic site and located at different places in the colon.

Six human CRC cell lines (Caco-2, HCT 116, HT 29, SW 48, SW 480, SW 620) were selected from the American Type Culture Collection (ATCC). Their characteristics and their respective CMS groups [34] are summarized in Table 4. Caco-2 cell lines were cultured without specific conditions, to keep the adenocarcinoma profile and not an intestinal epithelial barrier. Caco-2 has the advantage to be KRAS-wild type, to have a MDR system, and to come from the right colon. All the cell culture products were provided by SigmaAldrich (St-Quentin Fallavier, France), except for fetal bovine serum (FBS), which was purchased from Eurobio (Courtaboeuf, France). The cell lines were cultured at $37^{\circ} \mathrm{C}$ in a humidified atmosphere in the presence of $5 \% \mathrm{CO}_{2}$ in RPMI (Roswell Park Memorial Institute), 1640 were supplemented with $10 \%$ decomplemented FBS (20\% FBS for Caco-2 cells), $1 \%$ L-glutamine and $1 \%$ penicilline-streptomicine. All cell lines were tested to be mycoplasma-free. 
Table 4. Characteristics of the six colorectal cancer (CRC) cell lines used in the study, including molecular characteristics (mutations are annotated at the protein level, as described by den Dunnen et al. [45]; wt: wild type) and the relevant consensus molecular subtypes (CMS) groups according to Sveen et al. [38].

\begin{tabular}{|c|c|c|c|c|c|c|}
\hline $\begin{array}{l}\text { CRC Cell Line } \\
\text { Designation }\end{array}$ & Caco-2 & HCT116 & HT-29 & SW48 & SW480 & SW620 \\
\hline $\begin{array}{c}\text { (ATCC } \\
\text { Number) }\end{array}$ & (НTB-37) & (CCL-247) & (НTB-38) & (CCL-231) & (CCL-228) & (CCL-227) \\
\hline $\begin{array}{c}\text { Image (Day 1; } \\
\text { X20) }\end{array}$ & & & & & & \\
\hline Disease & $\begin{array}{l}\text { colorectal } \\
\text { carcinoma }\end{array}$ & $\begin{array}{l}\text { colorectal } \\
\text { carcinoma }\end{array}$ & $\begin{array}{l}\text { colorectal ade- } \\
\text { nocarcinoma }\end{array}$ & $\begin{array}{l}\text { colorectal ade- } \\
\text { nocarcinoma }\end{array}$ & $\begin{array}{l}\text { colorectal ade- } \\
\text { nocarcinoma }\end{array}$ & $\begin{array}{l}\text { colorectal ade- } \\
\text { nocarcinoma }\end{array}$ \\
\hline Primary tissue & colon & colon & colon & colon & colon & colon \\
\hline $\begin{array}{c}\text { Tumor } \\
\text { localization }\end{array}$ & colon & ascending colon & colon & $\begin{array}{l}\text { transverse } \\
\text { colon }\end{array}$ & $\begin{array}{l}\text { descending } \\
\text { colon }\end{array}$ & $\begin{array}{l}\text { descending } \\
\text { colon }\end{array}$ \\
\hline Duke'stype & $\mathrm{n} / \mathrm{a}$ & $\mathrm{D}$ & $\mathrm{C}$ & $\mathrm{C}$ & B & $\mathrm{C}$ \\
\hline Grade & $\mathrm{n} / \mathrm{a}$ & $\mathrm{n} / \mathrm{a}$ & $\mathrm{n} / \mathrm{a}$ & IV & $\mathrm{n} / \mathrm{a}$ & $\mathrm{n} / \mathrm{a}$ \\
\hline Metastatic site & & & & & & lymph node \\
\hline $\begin{array}{l}\text { Patient age } \\
\text { (yo) }\end{array}$ & 72 & 48 & 44 & 83 & 50 & 51 \\
\hline Patient gender & male & male & female & female & male & male \\
\hline Ethnicity & caucasian & na & caucasian & caucasian & caucasian & caucasian \\
\hline $\begin{array}{c}\text { Genes } \\
\text { expressed }\end{array}$ & EGF & CEA & CEA & CEA & EGF & CEA \\
\hline TP53 & E204X & $w t$ & $\mathrm{R} 273 \mathrm{H}$ & wt & R273H;P309S & R273H;P309S \\
\hline K-ras & wt & G13D & wt & wt & G12V & G12V \\
\hline B-raf & wt & wt & V600E & wt & wt & wt \\
\hline PTEN & wt & wt & $\mathrm{Wt}$ & wt & wt & wt \\
\hline PIK3CA & wt & H1047R & $\mathrm{P} 449 \mathrm{~T}$ & wt & $w t$ & wt \\
\hline CIN & $x$ & & $x$ & & $x$ & $X$ \\
\hline MSS/MSI & MSS & MSI & MSS & MSI & MSS & MSS \\
\hline CMS & 4 & 4 & 3 & 1 & 4 & 4 \\
\hline
\end{tabular}

\subsection{Chemotherapeutic Drugs}

A total of 13 molecules were tested, currently used in CRC or not. Twelve cytotoxic agents, all of which are routinely used in colorectal cancer for systemic treatment (oxaliplatin, 5-FU, irinotecan, but also raltitrexed and paclitaxel used in case of contra-indications to fluoropyrimidine). We included chemotherapeutic agents used for intra-arterial treatments and idarubicin, the best candidate after in-vitro screening on HCC cell lines [27]. We selected (a) three anthracyclines: doxorubicin $(200 \mathrm{mg} / 100 \mathrm{~mL}$; Teva Sante, Courbevoie, France); idarubicin (10 mg/10 mL; Zavedos, Pfizer, Paris, France) ; epirubicin 50 mg/25 mL; Mylan, Paris, France), (b) one alkylating antibiotic (mitomycin C, 10 mg; Kyowa Kirin Pharma, Neuilly-Sur-Seine, France), (c) three anti-metabolites: 5-FU (5 g/100 mL; Accord Healthcare, Lille, France); gemcitabine (38 mg/mL; Hospira, Meudon, France); raltitrexed (2 mg; Sigma-Aldrich, Saint-Louis, MO, USA), (d) one DNA topoisomerase inhibitor: irinotecan (500 mg/25 mL; Hospira, Meudon, France), (e) two platinum derivatives: oxaliplatin (200 mg/40 mL; Accord Healthcare, Lille, France); cisplatin (100 mg/100 mL; Accord Healthcare, Lille, France), (f) one antitumoral antibiotic: streptozotocin (1 g; Zanozar, 
Keocyt, Montrouge, France) and (g) one taxane: paclitaxel (300 mg/50 mL; Hospira, Meudon, France). We also included the vector used for drug mixture in c-TACE: lipiodol (480 mg Iode/mL; Guerbet, Villepinte, France). Because raltitrexed was not available in the cytotoxic lab of the university hospital, this molecule was used from a pure chemical powder form, reconstituted in the research lab according to the manufacturer's recommendations. The 12 other molecules we used, which were in their marketed pharmaceutical form, came from the cytotoxic lab of the university hosital in solution form (in sterile $10 \mathrm{~mL}$ syringes). Only two of them (mitomycin C and streptozocin) had beforehand been reconstituted from powder form in RPMI. All the solutions were used after warming at $37^{\circ} \mathrm{C}$. The maximal concentrations used (C Max) for the present study were: doxorubicin $2 \mathrm{mg} / \mathrm{mL}$; idarubicin $1 \mathrm{mg} / \mathrm{mL}$; epirubicin $2 \mathrm{mg} / \mathrm{mL}$; mitomycin C $1 \mathrm{mg} / \mathrm{mL} ; 5$-FU $50 \mathrm{mg} / \mathrm{mL}$; gemcitabine $38 \mathrm{mg} / \mathrm{mL}$; raltitrexed $0.5 \mathrm{mg} / \mathrm{mL}$; irinotecan $20 \mathrm{mg} / \mathrm{mL}$; oxaliplatin $5 \mathrm{mg} / \mathrm{mL}$; cisplatin $1 \mathrm{mg} / \mathrm{mL}$; streptozotocin $200 \mathrm{mg} / \mathrm{mL}$; paclitaxel $6 \mathrm{mg} / \mathrm{mL}$; bevacizumab $25 \mathrm{mg} / \mathrm{mL}$, and lipiodol $480 \mathrm{mg}$ Iodine $/ \mathrm{mL}$.

\subsection{Screening Protocol}

All the manipulations were carried out by two independent operators with, respectively, 4 and 27 years of experience in cell cultures and experimental studies. Cell lines were detached (Day 0) with a mixture of 0.05\% trypsine/0.5 mM EDTA (Sigma-Aldrich, Saint-Louis, MO, USA) after rinsing with Dulbecco's Phosphate Buffered Saline (PBS). Cells were seeded onto a 96-well tissue culture-plate, 10,000 cells per well, and cultured for $24 \mathrm{~h}$. At Day 1, the culture medium was changed to lower the FBS level to $0.5 \%$. Drugs with the maximal concentration were deposited in the first column of the plate and we attended to successive three-fold dilutions with fresh RPMI containing $0.5 \%$ FBS. The last column (Column 12) of the plate contained drug-free medium. The cells were exposed to drugs for $30 \mathrm{~min}$ at $37^{\circ} \mathrm{C}$ before being washed twice or thrice if the drugs were viscous or stained with RPMI ( $0.5 \%$ FBS). The cells were then put back in the incubator for $72 \mathrm{~h}$. For each condition (type of molecule, concentration of molecule and cell line type), replicates $(n=4)$ were tested during the same experience. Each experience was repeated three times $(N=3)$, as previously described for a total period of four months.

\subsection{Cytotoxicity Assay}

At Day 4, to evaluate the effect of drugs on cell viability, we performed spectrophotometric quantification by using the WST-1 Cell Viability Assay (WST-1, Sigma-Aldrich, Saint-Louis, MO, USA). Ten $\mu \mathrm{L}$ WST-1 per well were added to $100 \mu \mathrm{L}$ of medium. After $2 \mathrm{~h}$ of incubation at $37^{\circ} \mathrm{C}$, the plate was shacked and absorbance was read on a microplate reader (Asys Hitech, Eugendorf, Austria) at $440 \mathrm{~nm}$ incubation in a humidified atmosphere $\left(37^{\circ} \mathrm{C}, 5 \% \mathrm{CO}_{2}\right)$, as recommended by the WST-1manufacturer.

\subsection{Statistical and Data Analysis}

The mean \pm standard deviation of the repetition $(N=3)$ obtained from the mean of each quadruplicates was calculated. After normalization with the control $(100 \%$ of viability), the viability curves were generated for the six cell lines treated by each of the 12 drugs, the lipiodol and the bevacizumab (Figures 1-8). On each curve, a horizontal reference line corresponding to $10 \%$ of cell viability was represented.

The dose-response data were fitted by a four-parameter logistic nonlinear regression model (Equation (1)), modified from the original Hill equation [46]

$$
\frac{O D(c)-O D_{\text {baseline }}(c)}{O D(0)}=\alpha+\frac{1-\beta}{1+\frac{c}{\gamma} \delta^{\delta}}
$$

where $c$ is the drug concentration, $O D(c)$ is the optic density (OD) at the concentration of drug $c, O D_{\text {baseline }}(c)$ is the optic density of the rpmi and drug only and $(\alpha, \beta, \gamma, \delta)$ are the four estimated parameters of the dose-response model. The Raltitrexed drug showed 
a different dose response pattern and was fitted using a biphasic dose response curve corresponding to a balanced sum of two Hill functions. The Matlab (MathWorks ${ }^{\circledR} ; \mathrm{R} 2018 \mathrm{~b}$; Natick, MA, USA) non-linear solver (Curve Fitting Toolbox) estimated the parameters of the dose response function for each of the cell lines and drug conditions. Based on the fitted curve, we extracted the $\mathrm{IC}_{50}$ and $\mathrm{IC}_{90}$, which correspond to the drug concentration $(\mathrm{mg} / \mathrm{mL})$ required to obtain $50 \%$ and $90 \%$ of cell death, respectively. Finally, we calculated the $\mathrm{CyI}_{90}$ cytotoxicity index, corresponding to the ratio of the maximal drug concentration to $\mathrm{IC}_{90}\left(\mathrm{CyI}_{90}=\mathrm{C} \mathrm{Max} / \mathrm{IC}_{90}\right)$, according to Boulin et al. [27]. For example, a CyI $\mathrm{I}_{90}$ of 1000 means that the drug kills $90 \%$ of the cells even when diluted (1:1000). The $\mathrm{IC}_{50}, \mathrm{IC}_{90}$, and $\mathrm{CyI}_{90}$ values are represented in Tables 1-3. To compare each molecule effect on each cell line, the mean of $\mathrm{CyI}_{90}$ was tested with a one-way ANOVA. Whenever there was a significant mean difference between the drugs, an additional post-hoc test (Fisher's LSD) was conducted. A $p$ value $<0.05$ was considered statistically significant. Results were reported as mean \pm standard deviation for each cell lines.

All the statistical analyses were performed with Statistica $\left(\mathrm{TIBCO}^{\circledR}\right.$ Software; 13.4.0.14; Palo Alto, CA, USA).

\section{Conclusions}

The most commonly used anticancer drugs (5-FU, oxaliplatin, irinotecan, raltitrexed) in CRC have a very limited cytotoxicity effect on CRC cell lines after short exposure time (30 min). On the contrary, idarubicin (and partially gemcitabine) exhibits a strong cytotoxicity profile (over CMS1, 3, 4 cell lines, independently of RAS status). These results argue for further trials of idarubicin (optionally combined with gemcitabine) for the intraarterial treatment of CRC liver metastases in patients with unresectable CRLM. In the same way, the poor patient prognosis associated with CMS4 warrants additional studies to pursue the potential for clinical testing of HSP90 inhibitor repositioning and combination therapy with idarubicin in colorectal cancer.

Supplementary Materials: The following are available online at https:/ /www.mdpi.com/article/ 10.3390/ph14070639/s1, Figure S1: Colorectal cancer cell line viability curves after a 30-min timecontact with lipiodol. The horizontal red line represents $10 \%$ of cell viability. Table S1: Statistical analysis (LSD-Fisher) for cell viability curves. Values represents the LSD-Fisher p-value for any concentration versus control, for each drug and each cell line.

Author Contributions: Conceptualization, A.F., K.B., C.G., E.A.P., M.B. and B.G.; data curation, A.F., K.B., J.B. and M.N.; formal analysis, A.F., M.N. and E.A.P.; funding acquisition, A.F.; investigation, A.F., K.B. and J.B.; methodology, A.F., K.B., E.A.P. and M.B.; project administration, A.F., M.B. and B.G.; resources, C.G., C.B. (Cécile Breuil) and M.B.; software, M.N.; supervision, M.B. and B.G.; validation, E.A.P. and B.G.; writing—original draft, A.F.; writing—review and editing, K.B., E.A., C.B. (Céline Bazille) and B.G. All authors have read and agreed to the published version of the manuscript.

Funding: CNRS and the University of Caen. This research was supported in part by a grant provided by the Société Française de Radiologie-French Society of Radiology — SFR together with the Collège des Enseignants en Radiologie de France-French Academic College of Radiology (CERF).

Institutional Review Board Statement: Not applicable.

Informed Consent Statement: Not applicable.

Data Availability Statement: The data presented in this study are available in the main text and supplementary material.

Acknowledgments: The authors thank the cytostatic lab of the University Hospital of Caen.

Conflicts of Interest: The authors declare no conflict of interest related to this study. 


\section{References}

1. Bray, F.; Ferlay, J.; Soerjomataram, I.; Siegel, R.L.; Torre, L.A.; Jemal, A. Global Cancer Statistics 2018: GLOBOCAN Estimates of Incidence and Mortality Worldwide for 36 Cancers in 185 Countries. CA Cancer J. Clin. 2018, 68, 394-424. [CrossRef] [PubMed]

2. Bhutiani, N.; Martin, R.C.G. Transarterial Therapy for Colorectal Liver Metastases. Surg. Clin. N. Am. 2016, 96, 369-391. [CrossRef] [PubMed]

3. Ferlay, J.; Soerjomataram, I.; Dikshit, R.; Eser, S.; Mathers, C.; Rebelo, M.; Parkin, D.M.; Forman, D.; Bray, F. Cancer Incidence and Mortality Worldwide: Sources, Methods and Major Patterns in GLOBOCAN 2012. Int. J. Cancer 2015, 136, E359-E386. [CrossRef]

4. Heinemann, V.; Weikersthal, L.F.; von Decker, T.; Kiani, A.; Vehling-Kaiser, U.; Al-Batran, S.-E.; Heintges, T.; Lerchenmüller, C.; Kahl, C.; Seipelt, G.; et al. FOLFIRI plus Cetuximab versus FOLFIRI plus Bevacizumab as First-Line Treatment for Patients with Metastatic Colorectal Cancer (FIRE-3): A Randomised, Open-Label, Phase 3 Trial. Lancet Oncol. 2014, 15, 1065-1075. [CrossRef]

5. Venook, A.P.; Niedzwiecki, D.; Lenz, H.J.; Innocenti, F.; Fruth, B.; Meyerhardt, J.A.; Schrag, D.; Greene, C.; O’Neil, B.H.; Atkins, J.N.; et al. Effect of First-Line Chemotherapy Combined with Cetuximab or Bevacizumab on Overall Survival in Patients with KRAS Wild-Type Advanced or Metastatic Colorectal Cancer a Randomized Clinical Trial. JAMA J. Am. Med. Assoc. 2017, 317, 2392-2401. [CrossRef]

6. Cremolini, C.; Loupakis, F.; Antoniotti, C.; Lupi, C.; Sensi, E.; Lonardi, S.; Mezi, S.; Tomasello, G.; Ronzoni, M.; Zaniboni, A.; et al. FOLFOXIRI plus Bevacizumab versus FOLFIRI plus Bevacizumab as First-Line Treatment of Patients with Metastatic Colorectal Cancer: Updated Overall Survival and Molecular Subgroup Analyses of the Open-Label, Phase 3 TRIBE Study. Lancet Oncol. 2015, 16, 1306-1315. [CrossRef]

7. Assenat, E.; Desseigne, F.; Thezenas, S.; Viret, F.; Mineur, L.; Kramar, A.; Samalin, E.; Portales, F.; Bibeau, F.; Crapez-Lopez, E.; et al. Cetuximab Plus FOLFIRINOX (ERBIRINOX) as First-Line Treatment for Unresectable Metastatic Colorectal Cancer: A Phase II Trial. Oncologist 2011, 16, 1557-1564. [CrossRef]

8. Zhao, B.; Wang, L.; Qiu, H.; Zhang, M.; Sun, L.; Peng, P.; Yu, Q.; Yuan, X. Mechanisms of Resistance to Anti-EGFR Therapy in Colorectal Cancer. Oncotarget 2017, 8, 3980-4000. [CrossRef] [PubMed]

9. Axelrad, J.; Kriplani, A.; Ozbek, U.; Harpaz, N.; Colombel, J.F.; Itzkowitz, S.; Holcombe, R.F.; Ang, C. Chemotherapy Tolerance and Oncologic Outcomes in Patients With Colorectal Cancer With and Without Inflammatory Bowel Disease. Clin. Colorectal Cancer 2017, 16, e205-e210. [CrossRef]

10. Breedis, C.; Young, G. The Blood Supply of Neoplasms in the Liver. Am. J. Pathol. 1954, 30, 969-977. [PubMed]

11. Kan, Z.; Madoff, D.C. Liver Anatomy: Microcirculation of the Liver. Semin. Interv. Radiol. 2008, 25, 77-85. [CrossRef]

12. Bugyik, E.; Renyi-Vamos, F.; Szabo, V.; Dezso, K.; Ecker, N.; Rokusz, A.; Nagy, P.; Dome, B.; Paku, S. Mechanisms of Vascularization in Murine Models of Primary and Metastatic Tumor Growth. Chin. J. Cancer 2016, 35, 1-8. [CrossRef] [PubMed]

13. Lencioni, R.; de Baere, T.; Soulen, M.C.; Rilling, W.S.; Geschwind, J.-F.H. Lipiodol Transarterial Chemoembolization for Hepatocellular Carcinoma: A Systematic Review of Efficacy and Safety Data. Hepatology 2016, 64, 106-116. [CrossRef] [PubMed]

14. De Baere, T.; Tselikas, L.; Boige, V.; Ducreux, M.; Malka, D.; Goéré, D.; Benahim, E.; Deschamps, F. Intra-Arterial Therapies for Colorectal Cancer Liver Metastases (Radioembolization Excluded). Bull. Cancer 2016. [CrossRef]

15. Kemeny, N.; Daly, J.; Reichman, B.; Geller, N.; Botet, J.; Oderman, P. Intrahepatic or Systemic Infusion of Fluorodeoxyuridine in Patients with Liver Metastases from Colorectal Carcinoma. A Randomized Trial. Ann. Intern. Med. 1987, 107, 459-465. [CrossRef]

16. Ducreux, M.; Ychou, M.; Laplanche, A.; Gamelin, E.; Lasser, P.; Husseini, F.; Quenet, F.; Viret, F.; Jacob, J.-H.; Boige, V.; et al. Hepatic Arterial Oxaliplatin Infusion plus Intravenous Chemotherapy in Colorectal Cancer with Inoperable Hepatic Metastases: A Trial of the Gastrointestinal Group of the Federation Nationale Des Centres de Lutte Contre Le Cancer. J. Clin. Oncol. 2005, 23, 4881-4887. [CrossRef] [PubMed]

17. Boige, V.; Malka, D.; Elias, D.; Castaing, M.; De Baere, T.; Goere, D.; Dromain, C.; Pocard, M.; Ducreux, M. Hepatic Arterial Infusion of Oxaliplatin and Intravenous LV5FU2 in Unresectable Liver Metastases from Colorectal Cancer after Systemic Chemotherapy Failure. Ann. Surg. Oncol. 2008, 15, 219-226. [CrossRef] [PubMed]

18. Ranieri, G.; Laforgia, M.; Nardulli, P.; Ferraiuolo, S.; Molinari, P.; Marech, I.; Gadaleta, C.D. Oxaliplatin-Based Intra-Arterial Chemotherapy in Colo-Rectal Cancer Liver Metastases: A Review from Pharmacology to Clinical Application. Cancers 2019, 11, 141. [CrossRef]

19. Swierz, M.J.; Storman, D.; Riemsma, R.P.; Wolff, R.; Mitus, J.W.; Pedziwiatr, M.; Kleijnen, J.; Bala, M.M. Transarterial (Chemo) Embolisation versus No Intervention or Placebo for Liver Metastases. Cochrane Database Syst. Rev. 2020, 2020, CD009498. [CrossRef]

20. Mocellin, S.; Pilati, P.; Lise, M.; Nitti, D. Meta-Analysis of Hepatic Arterial Infusion for Unresectable Liver Metastases from Colorectal Cancer: The End of an Era? J. Clin. Oncol. 2007, 25, 5649-5654. [CrossRef]

21. Mocellin, S.; Pasquali, S.; Nitti, D. Fluoropyrimidine-HAI (Hepatic Arterial Infusion) versus Systemic Chemotherapy (SCT) for Unresectable Liver Metastases from Colorectal Cancer. Cochrane Database Syst. Rev. 2009, CD007823. [CrossRef]

22. Pwint, T.P.; Midgley, R.; Kerr, D.J. Regional Hepatic Chemotherapies in the Treatment of Colorectal Cancer Metastases to the Liver. Semin. Oncol. 2010, 37, 149-159. [CrossRef] [PubMed]

23. Deschamps, F.; Rao, P.; Teriitehau, C.; Hakime, A.; Malka, D.; Boige, V.; Ducreux, M.; Elias, D.; Goere, D.; de Baere, T. Percutaneous Femoral Implantation of an Arterial Port Catheter for Intraarterial Chemotherapy: Feasibility and Predictive Factors of Long-Term Functionality. J. Vasc. Interv. Radiol. JVIR 2010, 21, 1681-1688. [CrossRef] [PubMed] 
24. Deschamps, F.; Elias, D.; Goere, D.; Malka, D.; Ducreux, M.; Boige, V.; Auperin, A.; de Baere, T. Intra-Arterial Hepatic Chemotherapy: A Comparison of Percutaneous Versus Surgical Implantation of Port-Catheters. Cardiovasc. Interv. Radiol. 2011, 34, 973-979. [CrossRef] [PubMed]

25. Tsitskari, M.; Filippiadis, D.; Kostantos, C.; Palialexis, K.; Zavridis, P.; Kelekis, N.; Brountzos, E. The Role of Interventional Oncology in the Treatment of Colorectal Cancer Liver Metastases. Ann. Gastroenterol. 2019, 32, 147-155. [CrossRef] [PubMed]

26. Varela, M.; Real, M.I.; Burrel, M.; Forner, A.; Sala, M.; Brunet, M.; Ayuso, C.; Castells, L.; Montañá, X.; Llovet, J.M.; et al. Chemoembolization of Hepatocellular Carcinoma with Drug Eluting Beads: Efficacy and Doxorubicin Pharmacokinetics. J. Hepatol. 2007, 46, 474-481. [CrossRef]

27. Boulin, M.; Guiu, S.; Chauffert, B.; Aho, S.; Cercueil, J.-P.; Ghiringhelli, F.; Krause, D.; Fagnoni, P.; Hillon, P.; Bedenne, L.; et al. Screening of Anticancer Drugs for Chemoembolization of Hepatocellular Carcinoma. Anti-Cancer Drugs 2011, 22, 741-748. [CrossRef]

28. Favelier, S.; Boulin, M.; Hamza, S.; Cercueil, J.-P.; Cherblanc, V.; Lepage, C.; Hillon, P.; Chauffert, B.; Krausé, D.; Guiu, B. Lipiodol Trans-Arterial Chemoembolization of Hepatocellular Carcinoma with Idarubicin: First Experience. Cardiovasc. Interv. Radiol. 2013, 36, 1039-1046. [CrossRef]

29. Boulin, M.; Hillon, P.; Cercueil, J.P.; Bonnetain, F.; Dabakuyo, S.; Minello, A.; Jouve, J.L.; Lepage, C.; Bardou, M.; Wendremaire, M.; et al. Idarubicin-Loaded Beads for Chemoembolisation of Hepatocellular Carcinoma: Results of the IDASPHERE Phase I Trial. Aliment. Pharmacol. Ther. 2014, 39, 1301-1313. [CrossRef]

30. Guiu, B.; Schmitt, A.; Reinhardt, S.; Fohlen, A.; Pohl, T.; Wendremaire, M.; Denys, A.; Blümmel, J.; Boulin, M. Idarubicin-Loaded ONCOZENE Drug-Eluting Embolic Agents for Chemoembolization of Hepatocellular Carcinoma: In Vitro Loading and Release and In Vivo Pharmacokinetics. J. Vasc. Interv. Radiol. JVIR 2015, 26, 262-270. [CrossRef]

31. Guiu, B.; Chevallier, P.; Assenat, E.; Barbier, E.; Merle, P.; Bouvier, A.; Dumortier, J.; Nguyen-Khac, E.; Gugenheim, J.; Rode, A.; et al. Idarubicin-Loaded Beads for Chemoembolization of Hepatocellular Carcinoma: The IDASPHERE II Single-Arm Phase II Trial. Radiology 2019, 291, 801-808. [CrossRef] [PubMed]

32. Boulin, M.; Schmitt, A.; Delhom, E.; Cercueil, J.-P.; Wendremaire, M.; Imbs, D.-C.; Fohlen, A.; Panaro, F.; Herrero, A.; Denys, A.; et al. Improved Stability of Lipiodol-Drug Emulsion for Transarterial Chemoembolisation of Hepatocellular Carcinoma Results in Improved Pharmacokinetic Profile: Proof of Concept Using Idarubicin. Eur. Radiol. 2016, 26, 601-609. [CrossRef] [PubMed]

33. Guiu, B.; Jouve, J.-L.; Schmitt, A.; Minello, A.; Bonnetain, F.; Cassinotto, C.; Piron, L.; Cercueil, J.-P.; Loffroy, R.; Latournerie, M.; et al. Intra-Arterial Idarubicin_lipiodol without Embolisation in Hepatocellular Carcinoma: The LIDA-B Phase I Trial. J. Hepatol. 2018, 68, 1163-1171. [CrossRef]

34. Guinney, J.; Dienstmann, R.; Wang, X.; De Reyniès, A.; Schlicker, A.; Soneson, C.; Marisa, L.; Roepman, P.; Nyamundanda, G.; Angelino, P.; et al. The Consensus Molecular Subtypes of Colorectal Cancer. Nat. Med. 2015, 21, 1350-1356. [CrossRef]

35. Song, N.; Pogue-Geile, K.L.; Gavin, P.G.; Yothers, G.; Kim, S.R.; Johnson, N.L.; Lipchik, C.; Allegra, C.J.; Petrelli, N.J.; O'Connell, M.J.; et al. Clinical Outcome from Oxaliplatin Treatment in Stage II/III Colon Cancer According to Intrinsic Subtypes: Secondary Analysis of NSABP C-07/NRG Oncology Randomized Clinical Trial. JAMA Oncol. 2016, 2, 1162-1169. [CrossRef]

36. Le, D.T.; Uram, J.N.; Wang, H.; Bartlett, B.R.; Kemberling, H.; Eyring, A.D.; Skora, A.D.; Luber, B.S.; Azad, N.S.; Laheru, D.; et al. PD-1 Blockade in Tumors with Mismatch-Repair Deficiency. N. Engl. J. Med. 2015, 372, 2509-2520. [CrossRef]

37. Trinh, A.; Trumpi, K.; De Sousa E Melo, F.; Wang, X.; De Jong, J.H.; Fessler, E.; Kuppen, P.J.K.; Reimers, M.S.; Swets, M.; Koopman, M.; et al. Practical and Robust Identification of Molecular Subtypes in Colorectal Cancer by Immunohistochemistry. Clin. Cancer Res. 2017, 23, 387-398. [CrossRef] [PubMed]

38. Sveen, A.; Bruun, J.; Eide, P.W.; Eilertsen, I.A.; Ramirez, L.; Murumagi, A.; Arjama, M.; Danielsen, S.A.; Kryeziu, K.; Elez, E.; et al. Colorectal Cancer Consensus Molecular Subtypes Translated to Preclinical Models Uncover Potentially Targetable Cancer Cell Dependencies. Clin. Cancer Res. 2018, 24, 794-806. [CrossRef]

39. Kornmann, M.; Fakler, H.; Butzer, U.; Beger, H.G.; Link, K.H. Oxaliplatin Exerts Potent in Vitro Cytotoxicity in Colorectal and Pancreatic Cancer Cell Lines and Liver Metastases. Anticancer Res. 2000, 20, 3259-3264.

40. Kornmann, M.; Butzer, U.; Blatter, J.; Beger, H.G.; Link, K.H. Pre-Clinical Evaluation of the Activity of Gemcitabine as a Basis for Regional Chemotherapy of Pancreatic and Colorectal Cancer. Eur. J. Surg. Oncol. 2000, 26, 583-587. [CrossRef]

41. Hofmann, C.; Buttenschoen, K.; Straeter, J.; Henne-Bruns, D.; Kornmann, M. Pre-Clinical Evaluation of the Activity of Irinotecan as a Basis for Regional Chemotherapy. Anticancer Res. 2005, 25, 795-804.

42. Matsumoto, K.; Nagahara, T.; Okano, J.-I.; Murawaki, Y. The Growth Inhibition of Hepatocellular and Cholangiocellular Carcinoma Cells by Gemcitabine and the Roles of Extracellular Signal-Regulated and Checkpoint Kinases. Oncol. Rep. 2008, 20, 863-872. [PubMed]

43. Garrido, C.; Chauffert, B.; Pinard, D.; Tibaut, F.; Genne, P.; Assem, M.; Dimanche-Boitrel, M.T. Circumvention of ConfluenceDependent Resistance in a Human Multi-Drug-Resistant Colon-Cancer Cell Line. Int. J. Cancer 1995, 61, 873-879. [CrossRef] [PubMed]

44. Roovers, D.J.; van Vliet, M.; Bloem, A.C.; Lokhorst, H.M. Idarubicin Overcomes P-Glycoprotein-Related Multidrug Resistance: Comparison with Doxorubicin and Daunorubicin in Human Multiple Myeloma Cell Lines. Leuk. Res. 1999, 23, 539-548. [CrossRef] 
45. Den Dunnen, J.T.; Antonarakis, S.E. Mutation Nomenclature Extensions and Suggestions to Describe Complex Mutations: A Discussion. Hum. Mutat. 2000, 15, 7-12. [CrossRef]

46. Hill, A.V. A New Mathematical Treatment of Changes of Ionic Concentration in Muscle and Nerve under the Action of Electric Currents, with a Theory as to Their Mode of Excitation. J. Physiol. 1910, 40, 190-224. [CrossRef] 